\title{
Critical factors in the evaluation of online media: creation and implementation of a measurement scale (e-SQ-Media)
}

\author{
Eduard Cristóbal-Fransi, $\mathrm{PhD}$ (corresponding author) \\ Department of Business Management, University of Lleida \\ C/ Jaume II, n. 73. 25001. Lleida, Spain Tel. (34) 973703242 \\ ecristobal@aegern.udl.cat \\ Francisco Hernández Soriano, $\mathrm{PhD}$ \\ Humanities School, University of Lleida, Spain \\ paco.hernandez@udl.cat \\ Frederic Marimon, $\mathrm{PhD}$ \\ Department of Business Management, Universitat Internacional de Catalunya, Spain \\ fmarimon@uic.es
}

\begin{abstract}
This paper seeks to develop and validate a measurement scale of perceived quality in the online media (e-SQ-Media), and to explore the influence of perceived quality on satisfaction and loyalty in the online media.Firstly, an explanation of the main attributes of the concepts examined is provided, with special attention being paid to the multidimensional nature of the variables and the relationships between them. This is followed by an examination of the validation processes of the measuring instruments. The validation process of scales suggested that the quality of service in online media is defined by a construct composed of four dimensions: efficiency; system availability; reliability and privacy; and interaction. The model, validated by means of structural equations, provides empirical evidence of the positive link between the quality dimensions proposed in the model and the constructs of satisfaction and loyalty.

Most relevant studies regarding quality in online media have focused in the identification of a set of indicators without taking into account aspects relating to perceived quality. The fusion of the two areas of knowledge (online media and e-service quality) may lead to the creation of a scale that takes advantage of the most beneficial features that provide us with the different areas of study with the aim of obtaining as balanced and convergent a model as possible.
\end{abstract}

Keywords: online media, perceived quality, communication, Web 2.0, online press, loyalty, satisfaction, e-services 


\section{INTRODUCTION}

One of the sectors on the Internet considered to have the highest growth potential is the online content industry, in general, and the virtual press in particular. The majority of the most important newspapers have their online editions that, despite initial concerns, have not suffered a fall in numbers of readers of their print versions. On the contrary, they are considered an added value that encourages reader loyalty (Hernández-Soriano and Cristóbal, 2014).

Some studies even reveal that the online press can manage to build loyalty among Internet users, that the newspapers on the Network are a reliable source of information and are well received, and even that the Network helps to increase the dissemination of printed dailies (Cristóbal and Gómez, 2004). However, there are also studies that show a significant increase in the figures of the demand for daily papers via the Internet (Kaye and Johnson, 2004; Flavián and Gurrea, 2009).

In addition, one can find studies that examine the content of the cybermedia (Maier, 2010), or, thanks to the Internet, citizens can participate in the creation of these contents in online newspapers (Nah et al., 2015).

Another object of study is the definition of the business model for implementation by the cybermedia. The printed press has traditionally obtained income from two sources: advertising and sales (Casero and Izquierdo, 2013; Picard, 2011). In the digital press however, this situation changes. Ease of access to free information on the web has made revenues suffer. Readers can access newspaper contents for free, even those of the paidfor print edition. This sometimes results in cannibalization between the two versions (Franklin, 2011). However, readers can accept paying for specialized information, such as financial news (Casero and Izquierdo, 2013). With no readership there are no advertisers, and without advertisers, there is no income. Internet has changed both the readers' and the advertisers' habits leading to changes in the two sources of income (Casero-Ripollés, 2010).

The choice of the subject is justified by the fact that increasingly payment is demanded for access to contents to make the maintenance of online editions feasible (Gallardo, 2011; Herbert and Thurman, 2007; Parra et al., 2008). Although most of the printed media is available on the Network, only a minority makes a profit. It is therefore necessary to ascertain which factors digital readers consider in order to deem the services they receive as being quality services with the aim of establishing a solvent, profitable business strategy.

\section{PERCEIVED QUALITY AND THE ONLINE MEDIA}

The Internet has enabled the emergence of new communications channels whose perceived quality cannot be analyzed using the methods known to date. Parasuraman et al. (2005) emphasize the fact that the scale must be adapted on the basis of the area of study and/or knowledge for research and improvement through the use of the principles that the model provides: "An important research priority is to examine the scales in the context of pure-service sites, make any necessary modifications, and assess the psychometric properties of the modified scales" (Parasuraman et al., 2005: 229). 
It was in 2005 that O'Reilly presented the concept of Web 2.0 and all that it implies, not only for commercial websites but also for the communications media. Soon the early works by authors such as Díaz-Noci $(2005)$ and Salaverría $(2003 ; 2005)$ began to appear describing Internet as an immature medium in which newspaper companies were missing out on the interactive capabilities offered by the Network, also highlighting the editorial immaturity of the industry using information portals at that time. It was then that the term Cybermedia was first coined: "The broadcaster of content with a will to mediate between facts and the public, fundamentally uses journalistic criteria and techniques, uses multimedia language, is interactive and hypertextual, is updated and is published on the Internet" (López et al., 2005: 40).

Today, the term is now sufficiently accepted both in academia and the professional field thanks to studies conducted in recent years by authors such as Thorson et al. (2012), Salaverría (2005), Meso (2007) and Díaz-Noci (2008). In spite of the work performed, the authors argue that it is a field of research that requires further theoretical and methodological development. However, one can point to some concrete proposals such as Cely's (2004) cybergraphy, the methodological studies by Palacios and Díaz-Noci (2009), the analysis method of Rodríguez-Martínez et al. (2010), or applied studies such as the one performed by Wurff, Lauf and O'Sullivan (2005), which consisted of a comparison of the printed and the online press in 16 European countries, including Spain.

Studies focusing on the perceived quality of the service provided by the cybermedia can also be found, such as the works of Codina et al., (2010), Rodríguez-Martínez et al., (2012) and Hernández-Soriano and Cristóbal, (2013) that start from a preliminary analysis of online digital resources where they begin to identify a series of terms and features as future indicators to determine the quality of the online newspaper for study. The aim is quite simple, higher quality assumes a greater number of visits that would translate, in terms of readership, into a greater number of advertisers and, in this way, securing a more competitive position of the communications medium on the Network.

The study of perceived quality, both in traditional and virtual businesses, has a long tradition and has been applied to a wide range of fields. One of the most prestigious and recognized contributions is the SERVQUAL model (Parasuraman et al. 1985; 1988 and 1991). It is a generic instrument to measure the quality provided by a service. Later, these authors developed a new instrument, E-S-QUAL, as a measurement scale that uses a pre-established series of items to determine the perceived quality of the services rendered by online businesses via websites (Parasuraman et al., 2005). Over time, the ES-QUAL model has been added to and has extended its scope of possibilities with the aim of improving the virtual establishment and achieving a higher number of sales. Authors such as Yang and Tsai (2007), Flavián and Gurrea (2006; 2009), Cristóbal et al., (2007), and Petnji et al., (2012) have developed different models based on the E-SQUAL scale to determine the factors that influence perceived quality. Consequently, a priori it seems that it could be adapted to the present case.

Thus, and on the basis of this background, it can be seen how the fields of study of Cybermedia and perceived quality have developed in the last decade without at any time converging, at least directly as has happened in other sectors mentioned above, as is the case of libraries (Garrido et al., 2012). 
Studies such as those of Codina et al., (2010) have sought to contribute their own models, identifying a set of indicators based on a review of the literature on Cybermedia, without taking into account aspects relating to the actual area of perceived quality itself. The fusion of the two areas of knowledge may lead to the creation of a scale that takes advantage of the most beneficial features that provide the different areas of study with the aim of obtaining as balanced and convergent a model as possible. The question is, therefore, to identify the most successful aspects in the various applications of the two areas in order to use them for a model whose deployment in enterprise is as effective and efficient as possible.

\section{THE E-SQ-MEDIA MODEL}

The principal objective lies in the creation of a scale for measuring perceived quality that can be applied to cybermedia using the work of Hernández and Cristóbal (2014) as a base where the dimensions for consideration in said scale were initially identified.

The proposed new scale, entitled e-SQ-MEDIA, leads to suggest the creation of a new dimension: Interaction. Based on this and the structural model set out below, the authors put forward the hypotheses of this research.

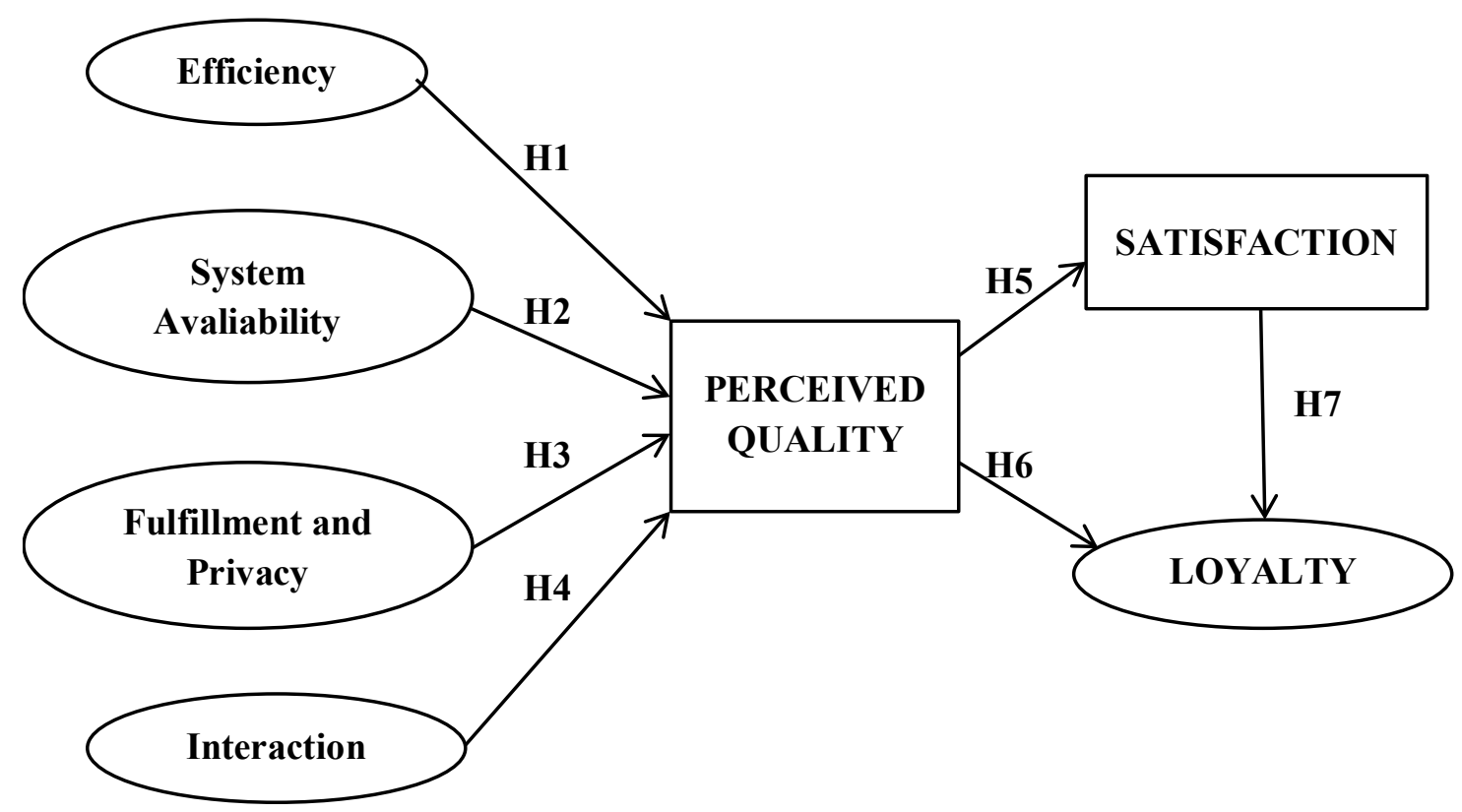

Figure 1: Proposed structural model, e-SQ-MEDIA.

The first dimension is Efficiency. This is a key factor in assessing the quality perceived by customers, regardless of the service that is the subject of study, with Zeithaml et al., (2000) being the first to determine that when it comes to products offered via the Network, consumers use similar dimensions.

Moreover, in a study conducted by Janita and Miranda (2008), it became clear that from the academic research conducted between 1997 and 2007, efficiency was one of the five 
dimensions into which the main items for measuring the perception of the quality of electronic services were grouped. This is also observed by Petnji et al., (2012) in an analysis of the E-S-QUAL model, where they examined studies carried out in eleven different countries and in which the Efficiency dimension appeared in each of the twenty studies examined as one of the final dimensions to be considered and evaluated regarding perceived quality.

Likewise, in several studies on cybermedia, efficiency is defined and included in the sections of "usability" and "visibility" (Rodríguez-Gairín, 2001; Codina, 2000) as another factor for consideration. Therefore, the first hypothesis can be put forward.

\section{H1: Efficiency has a positive impact on the perceived quality of the service of Cyber media.}

Starting out from the point of view of cybermedia, Rodríguez-Gairín (2001), based on prior studies by Codina (2000), uses access to the Web as a parameter in his study of quality indicators in the evaluation of electronic journals. Part of the importance of good information structuring will be conditioned, in turn, by good structural navigation through the Web of the electronic journal, as well as internal search systems that allow such access to information and the extent to which there are limitations as regards the language of the Web or other kinds of background knowledge needed to navigate on it.

However, as in the previous section, System Availability appeared in 19 of the 20 studies reviewed (in 11 different countries) by Petnji et al., (2012) as one of the dimensions to be taken into account when considering perceived quality. Thus, in one of the first uses of the concept by Lin and $\mathrm{Lu}$ (2000) and, as a result of the model of Parasuraman et al., (2005), other authors have also included this variable in their research, such as Yang and Tsai (2007), for instance. The second hypothesis can therefore be put forward.

\section{H2: System availability has a positive impact on the perceived quality of the service of Cybermedia.}

In the case of Cybermedia, whether or not they have an online store, to be able to perform the service (whether the information itself, or to provide the Internet user with the opportunity to interact with the medium, for example), the user must at some stage in the process register, and thus provide their data, and hence the provision and the privacy of the service become a whole, worthy of sharing a single dimension on the measurement scale carried out.

Studies such as those of Marimon et al. (2010), Rebolloso et al., (2004), and so on can be highlighted, who have followed the SERVQUAL outline of 5 items, reliability being one of them. The same applies to the E-S-QUAL scale, with authors such as Yang and Tsai (2007), Parasuraman et al., (2005), Vázquez et al., (2009), where reliability continues to be another item of the four pillars on which this new measurement scale of electronic services is based.

As for Privacy, it appeared in 17 of the 20 studies conducted on perceived quality through the E-S-QUAL method in an analysis carried out by Petnji et al., (2012). Garín and Pérez (2011) conclude that if people's trust in Internet security is improved, greater 
development and use of e-commerce can be achieved [in Spain]. Castillo and Sánchez Romero (2010) find that 53.3\% of Internet users do not contract services via the Internet due to fear or mistrust. Semeijn et al. (2005) conclude that the reliability of information results in the effect of an image of credibility and veracity in the eyes of the Internet user, which will lead to greater loyalty to the product. With the above in mind, the third hypothesis can be proposed.

\section{H3: Reliability and privacy have a positive impact on the perceived quality of the service of Cybermedia.}

As Rodriguez-Martinez et al., (2010: 42) state, "The success of the online media will greatly depend on their capacity to create Websites that allow for interaction both of the users with the content and the users amongst themselves". In this new model, the concept of interaction with the customer changes. Physical interaction with a transport service disappears and one must make way for a new term based on interaction where the customer-user participates in the contents of the information portal. This refers not only to interaction, but also to participation. Thus, the way people participate in media production and interact with media content (Carpentier, 2011) is analyzed using the term "Interaction" as one dimension.

On the other hand, despite not being an item used in the SERVQUAL or E-S-QUAL models, it is used as one of the three main pillars of the WEBQUAL scale (apart from information usability and quality), of which Barnes and Vidgen (2002: 114) make use: "A Web site that is difficult to use and interact with will project a poor image on the Internet and weaken the organization's position".

Returning to Cybermedia, Pérez and Perea (1998) emphasize that one of the seven characteristics of online information is to be Interactive and allow the audience itself to act as broadcaster and receiver at the same time. The same conclusion is reached by Kawamoto (2003) and Díaz and Salaverría (2003), among others, as they include interactivity as one of the basic features that must be presented by online information to the user or surfer. As a matter of fact, this does not only refer to interaction with media content (Carpentier, 2011).

Years later, Parra (2008) again underlined interactivity as one of "the three star vectors" of greatest importance within the cyberjournalistic genre. Moreover, Cebrián (2009) devotes an entire essay to interactive communication in Cybermedia. In 2012, Broekhuizen and Hoffman (2012), concluded that there is a relationship between the perception of online interactivity and the quality with which the information of an electronic newspaper is processed, and not only that but perceived interactivity is positively associated with the choice of an online newspaper over a printed newspaper. The fourth hypothesis is thus put forward.

\section{H4 Interaction has a positive impact on the perceived quality of the service of Cybermedia.}

While satisfaction would be the result of a transitory judgement, perceived quality would be the overall, final outcome maintained over time based on that or other value judgements about the service, which is precisely the conclusion reached by authors such as Parasuraman et al., (1988). They argue that the quality of the service, or the 
perception thereof, is determined by the customer's positive experiences over time: "Satisfaction is based on the experience of the service, while the perceived quality of the service is not necessarily based on the experience" (Alén and Fraiz, 2006: 255).

Cronin and Taylor (1992) were among the first to contradict the model posed by Parasuraman et al., (1988), indicating that quality is a precursor to satisfaction. More recently, this conclusion has also been reached by Espejel et al., (2007) in the field of olive oil, Marimon et al. (2010) on the quality perceived by supermarket customers, or De la Fuente and Díaz (2013) in their analysis of the determinants of the perceived quality of the service provided by a savings cooperative, among others. Due to all of the above, the fifth hypothesis can be proposed.

\section{H5: Perceived quality has a positive impact on the Internet user's satisfaction with the service of Cybermedia.}

Just as satisfaction is rather identified as a judgement or an affective state of the consumer following the consumption process (Oliver, 1997; Auh and Johnson, 2004; and Aamer, 2014), loyalty is defined as the result of this process (Jacoby and Chestnut, 1978). According to Auh and Johnson (2005) "loyalty is a customer's expectation or predisposition to repurchase from a particular product or service provider" (Auh and Johnson, 2005: 37). In fact, in this same study, the authors determined that satisfaction has a positive and very significant effect on loyalty.

More recent research also concludes that customer satisfaction has a significant impact on customer loyalty (Khan, 2012). This hypothesis is considered by other authors referring to the online world, such as Prado et al., (2013) who, in their study on satisfaction, loyalty and commitment in online environments, validated via their hypothesis that "The degree of satisfaction positively influences customer loyalty in the online environment" (Prado et al., 2013: 175). Therefore, the sixth hypothesis is put forward.

\section{H6: Internet user satisfaction has a positive impact on the loyalty of a Cybermedia user.}

According to Parasuraman et al. (1988), loyalty translates into two basic aspects: intention to repurchase and recommendation to other customers. In online daily newspapers, information portals and Cybermedia generally, it translates otherwise: "The visibility and popularity of the Cybermedia can be measured by the number of links from other Web sites, the number of pages published and indexed by this means; as well as by the number of visits it receives from a site and the number of pages served by it" (Said and Arcila, 2011: 127).

Mcllroy and Barnett (2000) refer to loyalty as a commitment that the client acquires for $\mathrm{him} /$ herself towards the company which is reflected in the purchase of its products and services as well as recommendation to friends, relatives and acquaintances. Kim and Yoon (2004) subscribe to Mcllroy and Barnett. Additionally, Marimon et al., (2010) also confirm their hypothesis that a high level of perceived quality on a website translates into high levels of loyalty to that same website. That same year, Yaghi (2010) also concluded that there is a direct relationship between perceived quality and customer loyalty. Although Petnji (2012) manages to partially support the relationship between 
the perceived service and loyalty, Marimon and Cristóbal (2012) again confirm the existence of a positive relationship between perceived quality and customer loyalty. Due to all of the above, the seventh and last hypothesis is proposed.

\section{H7: Perceived quality has a positive impact on the loyalty of a Cybermedia user.}

\section{METHODOLOGY}

An extensive review of the literature both concerning Cybermedia and Perceived Quality enabled identifying the main dimensions and the items that can be included in the scale, as reflected in Table 1. Items to measure customer satisfaction and loyalty are also included.

Table 1: Measurement scales of perceived quality in the Cybermedia, satisfaction and loyalty.

\begin{tabular}{|c|c|}
\hline \multicolumn{2}{|c|}{ EFFICIENCY } \\
\hline EF1 & Easy access to the Web \\
\hline EF2 & The information is well organized and easy to find \\
\hline EF3 & I can access the Web from my usual platform (PC, laptop, Smartphone, tablet, etc.) \\
\hline EF4 & The Website is visually attractive \\
\hline EF5 & In the first Website that I consulted it was easy to find the information I was looking for \\
\hline EF6 & The information is regularly updated \\
\hline EF7 & I can directly access the latest information \\
\hline EF8 & I can access the information I want from the homepage \\
\hline EF9 & I can access related information from the news item I am consulting \\
\hline EF10 & $\begin{array}{l}\text { To what degree do you value the multimedia support (videos and photos) of the information } \\
\text { published? }\end{array}$ \\
\hline EF11 & Easy access to and registration for purchasing and procurement \\
\hline EF12 & Easy access to participation in contents \\
\hline EF13 & Pop-up advertising is annoying and does not enable easy surfing \\
\hline EF14 & $\begin{array}{l}\text { It is useful for me to access the digital edition of the news using the Bidi-QR code of the printed } \\
\text { edition }\end{array}$ \\
\hline EF15 & I can register for and/or subscribe to the newspaper Website quickly and easily \\
\hline \multicolumn{2}{|c|}{ AVAILABILITY OF THE SYSTEM } \\
\hline D1 & The pages download quickly \\
\hline D2 & The Website often crashes \\
\hline D3 & The contents are well linked and redirect properly \\
\hline D4 & $\begin{array}{l}\text { I have had to install applications to be able to surf the Web and/or access various services or } \\
\text { contents }\end{array}$ \\
\hline D5 & I have required relatively complex computer skills to surf the Web \\
\hline D6 & The Website features an easy-to-use and easy-access search system \\
\hline D7 & $\begin{array}{l}\text { I have been able to contact those responsible for the different services and/or contents when } \\
\text { required }\end{array}$ \\
\hline D8 & The Website has 24-hour Customer Service \\
\hline \multicolumn{2}{|c|}{ RELIABILITY AND PRIVACY } \\
\hline CP1 & $\begin{array}{l}\text { It contains all the information I need to know about the features of the products, services and } \\
\text { content offered }\end{array}$ \\
\hline $\mathrm{CP} 2$ & $\begin{array}{l}\text { They confirm, once the purchasing process or participation in content is finished, that the } \\
\text { transaction has been carried out satisfactorily }\end{array}$ \\
\hline CP3 & The delivery service is performed within the date and time agreed \\
\hline CP4 & The delivered product is as shown on the web page \\
\hline CP5 & I am ensured as to the confidentiality of my data for all transactions \\
\hline CP6 & I am assured that I will not receive external commercial mails when I register \\
\hline CP7 & When I have a complaint or a claim, I am attended to quickly and effectively \\
\hline
\end{tabular}




\begin{tabular}{|l|l|}
\hline \multicolumn{2}{|l|}{ INTERACTION } \\
\hline I1 & I can participate in the creation of content of the Web \\
\hline I2 & I can participate via my usual social networks \\
\hline I3 & I can communicate with other users via the Web \\
\hline I4 & I can comment in the different sections of the Web: news, blogs, etc. \\
\hline I5 & I can sign up to receive information on the contents that interest me \\
\hline I6 & I can receive information via my usual platform (PC, laptop, tablet, Smartphone, etc.) \\
\hline I7 & I can vote on the information published \\
\hline \multicolumn{2}{|l|}{} \\
\hline PERCEIVED QUALITY OF THE CYBERMEDIA \\
\hline CP & Assess the Website in general \\
\hline USER SATISFACTION \\
\hline S & My experience with the Web has been satisfactory \\
\hline USER LOYALTY \\
\hline L1 & I would recommend this Website to friends and family \\
\hline L2 & I will be visiting the Web frequently \\
\hline
\end{tabular}

An online questionnaire was then developed, compiled from all the items identified in the review of the literature. Segre.com was the online daily newspaper chosen to carry out the study. Segre.com is part of the Segre Group of communications that in addition to its information portal is present in radio and television, and has a printed newspaper with a circulation of 110,000 copies. Segre.com has a constant public of 220,000 monthly visits.

Having collected the results, exploratory factorial analysis was performed on the items of the scale, using the principal components method, with Varimax rotation to see the number of factors obtained and whether or not they corresponded with the number and distribution of the dimensions of the proposed model. Also, having obtained and studied these subscales, a reliability analysis was performed on them so as then to proceed to perform confirmatory factor analysis of the dimensions obtained, and the observable variables (items) that comprise them, in order to proceed with their validation and the estimation of the model proposed in the present work.

\section{RESULTS}

The survey included a total of 265 participations. This figure complies with the conditions set out by Fabrigar et al., (1999) that recommend a sample size greater than 200. Manfreda et al., (2008) compare the sample size of 45 different studies with a statistical mode of 115 participations concluding that indicators such as GFI, IFI, TLI, and RMSEA are not sensitive to sample size. However, when preparing the results of this study, it was not possible to use all of them since the sample had to be cleaned up. Cleaning-up involved eliminating a number of participations on the basis of two criteria: first, all those whose average responses (3) were $50 \%$ or higher of the total, and all of those whose response pattern was constant after a point in the evaluation. Finally, a total of 211 valid surveys was obtained.

The profile of reader respondents is as follows: they are experienced $(95.3 \%$ connected more than three years ago) and loyal (75.8\% more than a year as a reader) surfers; they access the website quite often (56.9\% daily access to the online media website); they mainly access from home (85.3\%); they are newspaper readers (43.1\% read one daily); more than half have completed "undergraduate" studies $(51.2 \%)$; they are active workers (70.6\%); most of them are women (56.9\%); and most are middle-aged (57.8\% of respondents are in the 25 to 44 age group). 
Before performing factorial analysis a check was performed, with the sample obtained, to see whether said analysis was possible. Based on this, and on the correlations matrix, two tests were conducted: Bartlett's test of sphericity and the Kaiser-Meyer-Olkin index (KMO). The KMO index verifies whether the partial correlations between the variables are sufficiently small. A value of less than 0.6 would mean that it should not be used in factorial analysis with the sample data being analysed. In this case the value is 0.884 . On the other hand, Bartlett's statistic, which confirms the existence of linear dependence between the variables and justifies the continuity of the procedure, takes the value $\chi^{2}=2,363.478$ with 190 degrees of freedom and with a significance level of 0.000 , thus allowing the rejection of the null hypothesis of non-correlation between the variables observed. Therefore, it is appropriate to apply factorial analysis.

Based on all of the above, the authors proceeded to eliminate those items that show high secondary loads and whose items are quite similar. Thus, D3, D6, D7 and D8 presented not only high secondary loads but also disparity when being considered in one dimension or another. The same occurred with FP1, FP7, I2, EF10, EF14, and EF15. As a result, four factors that explain $65 \%$ of the variance with a total of 20 items were obtained (see Table 2).

Table 2: Final rotated component matrix with a total of 4 factors identified

\begin{tabular}{|l|c|c|c|c|}
\hline \multirow{2}{*}{ ITEMS } & \multicolumn{4}{|c|}{ Component } \\
\hline & $\mathbf{1}$ & $\mathbf{2}$ & $\mathbf{3}$ & $\mathbf{4}$ \\
\hline EF2 & 0.782 & & & \\
\hline EF9 & 0.765 & & & \\
\hline EF5 & 0.760 & & & \\
\hline EF1 & 0.716 & & & \\
\hline EF7 & 0.715 & & & \\
\hline EF8 & 0.712 & & & \\
\hline EF6 & 0.653 & & & \\
\hline D1 & 0.646 & & & \\
\hline CP4 & & 0.833 & & \\
\hline CP5 & & 0.819 & & \\
\hline CP3 & & 0.807 & & \\
\hline EF11 & & 0.734 & & \\
\hline CP6 & & 0.717 & & \\
\hline CP2 & & 0.628 & & \\
\hline D4 & & & 0.883 & \\
\hline D5 & & & 0.873 & \\
\hline D2 & & & 0.756 & \\
\hline I7 & & & & 0.773 \\
\hline I4 & & & & 0.741 \\
\hline I5 & & & & 0.665 \\
\hline
\end{tabular}

Table 3 shows the reliability analysis and internal consistency of the four quality dimensions. Both the Cronbach alphas and the indices of composite reliability show higher values than the recommended value of 0.7 , guaranteeing their reliability. 
Table 3: Subscale reliability analysis

\begin{tabular}{|l|l|c|c|c|}
\hline \multicolumn{1}{|c|}{ SUBSCALES } & \multicolumn{1}{|c|}{ ITEMS } & $\begin{array}{c}\text { COMPOSITE } \\
\text { RELIABILITY }\end{array}$ & $\begin{array}{c}\text { CRONBACH'S } \\
\text { ALPHA }\end{array}$ & AVE \\
\hline Efficiency & $\begin{array}{l}\text { EF1, EF2, EF5, } \\
\text { EF6, EF7, EF8, } \\
\text { EF9, D1 }\end{array}$ & 0.896 & 0.89 & 0.52 \\
\hline System Availability & D2, D4, D5 & 0.877 & 0.81 & 0.70 \\
\hline $\begin{array}{l}\text { Reliability and } \\
\text { Privacy }\end{array}$ & $\begin{array}{l}\text { CP2, CP3, CP4, } \\
\text { CP5, CP6, }\end{array}$ & 0.890 & 0.90 & 0.58 \\
\hline Interaction & EF11 & 0.771 & 0.74 & 0.53 \\
\hline
\end{tabular}

On the other hand, within this parameter of the analysis of validity, the AVE, or variance extracted, has been calculated, which measures whether the variance can be explained by means of the chosen indicators so that the larger the value, the more representative are the indicators of the dimension on which they load (Fornell and Larcker, 1981). Baggozi and Yi (1998) recommend they should be higher than 0.5, which would indicate that more than $50 \%$ of the variance of the construct is represented by its indicators. On this occasion, the results are positive again as they are all above 0.5 . The items of System Availability and Reliability and Privacy stand out with higher explanatory loads of the variance than the rest.

Regarding discriminant validity, this implies that each subscale or construct of the model should be significantly different from the other constructs. Therefore, the AVE value must be higher than the variance shared between a subscale and the rest so that, when performing correlations between them, the value on the diagonal (corresponding to the square root of the AVE values of each of them) should be greater than the other factors of each row and column that corresponds to it (see Table 4).

Table 4: Discriminant validity among subscales

\begin{tabular}{|l|c|c|c|c|}
\hline Constructs & Efficiency & $\begin{array}{c}\text { Reliability } \\
\text { and Privacy }\end{array}$ & $\begin{array}{c}\text { System } \\
\text { availability }\end{array}$ & Interaction \\
\hline Efficiency & $\mathbf{0 . 7 2 0}$ & & & \\
\hline Reliability and Privacy & 0.573 & $\mathbf{0 . 7 6 0}$ & & \\
\hline System availability & 0.114 & 0.252 & $\mathbf{0 . 8 3 0}$ & \\
\hline Interaction & 0.575 & 0.687 & 0.189 & $\mathbf{0 . 7 2 7 9}$ \\
\hline
\end{tabular}


Thus, one can observe not only that the values of the correlations are less than the square root of the AVE in the corresponding rows and columns but also that the existing correlations between the dimensions comprising the construct are not greater than 0.8 , as Bagozzi and Yi (1988) indicate. The highest correlation is found between the Reliability and Privacy and Interaction dimensions, whereas it is between Efficiency and System Availability that there is a certain distancing. Also important is the relationship between Efficiency and Reliability and Privacy, and between Efficiency and Interaction. In short, in this case the discriminant validity of the subscales is accepted and the internal consistency of the model can be ensured.

A review of the model's goodness of fit was then conducted. First the first part of the proposed e-SQ-MEDIA model was tested, i.e., the relationship between the items and each dimension and between the dimensions themselves.

The indicators show a GFI (Goodness of Fit Index) of 0.877 , which means that the variability of the data fits almost $88 \%$ with the proposed scale, slightly below the desired $90 \%$, though it should be borne in mind that the sample was just over 200 individuals. However, the IFI (Incremental Fix Index) is 0.93, which is a highly significant value since the indicator is less sensitive to sample size, indicating that the model fits well and is correct. Furthermore, both the TLI (Tucker-Lewis Index) and the CFI (Comparative Fit Index), close to 1 and above 0.9, and the RMSEA (Root Mean Square Error of Approximation) preferably below 0.08, since this is the error that would occur being applied to other population samples, fit perfectly. In summary, according to McDonald and Ho (2002) and given the results obtained, it can be stated that the model fits quite well and demonstrates clear internal consistency with a view to future research related to the variables that comprise it. 
Figure 2. Structural model of the proposed dimensions

The quality of fit of the entire model was examined next. Figure 2 shows the model with the loads and coefficients between constructs.

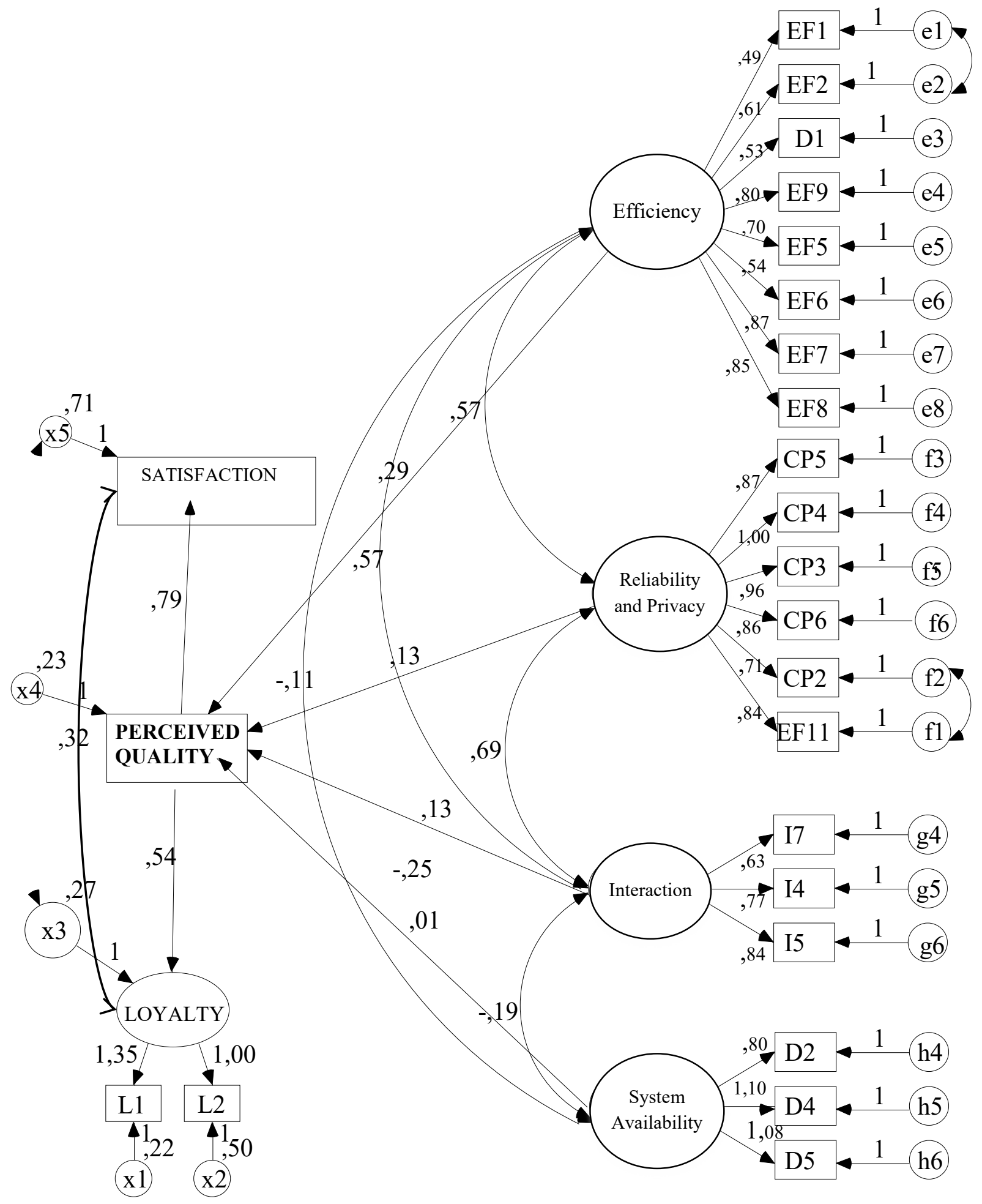


The indicators show first a GFI of 0.867 , slightly below the recommended limit. However, other indicators of fit are satisfactory. The IFI is 0.93 , which is sufficiently significant to indicate that the model is correct. Likewise, both the TLI and the CFI are close to 1 and above 0.9 , and the RMSEA is well below 0.8 , thus presenting excellent fit and internal consistency.

Table 5 shows that three of the four coefficients of the dimensions of quality and the item that measures perceived quality globally are significant at 0.05 significance level. Indeed, the "efficiency" dimension is the one that most contributes to explaining overall quality, with a standardized coefficient of 0.434 . Moreover, the impact of the "reliability and privacy" and "interaction" dimensions have an equal value far from the previous one (0.190). Finally it can be noted that "system availability" does not have an impact on overall quality. Therefore, three of the first four hypotheses are confirmed.

The four items show a positive relationship with regard to Perceived Quality, with Efficiency being the one to show the highest value, 43\%, while Reliability and Privacy, and Interaction each share $20 \%$, and so these two variables have the same effect on Perceived Quality. However, System Availability has the lowest value, at 2\%.

When analysing the structural part of the model it was observed that perceived quality is a clear premise for Internet user satisfaction. The standardized coefficient of the ratio is 0.533 , with a highly robust associated t-value. Similarly, perceived quality has a similar impact with loyalty $(0.578$ and associated t-value of 7.111$)$.

It can be seen, therefore, that satisfaction is mediating between perceived quality and loyalty. Thus, the overall effect of quality on loyalty is 0.323 ( $\mathrm{t}$-value $=0.5844$ ).

Table 5. Summary results of the hypotheses put forward

\begin{tabular}{|c|l|c|c|c|}
\hline HYPOTHESIS & \multicolumn{1}{|c|}{ RELATIONSHIP } & $\begin{array}{c}\text { Standardized } \\
\text { coefficient }\end{array}$ & t-value & RESULT \\
\hline H1 & Efficiency $\rightarrow$ Perceived Quality & 0.434 & 5.742 & Accepted \\
\hline H2 & $\begin{array}{l}\text { System Availability } \rightarrow \text { Perceived } \\
\text { Quality }\end{array}$ & 0.016 & 0.039 & Not Accepted \\
\hline H3 & $\begin{array}{l}\text { Reliability and Privacy } \rightarrow \text { Perceived } \\
\text { Quality }\end{array}$ & 0.190 & 2.138 & Accepted \\
\hline H4 & Interaction $\rightarrow$ Perceived Quality & 0.190 & 1.980 & Accepted \\
\hline H5 & Perceived Quality $\rightarrow$ Satisfaction & 0.533 & 9.117 & Accepted \\
\hline H6 & Satisfaction $\rightarrow$ Loyalty & 0.323 & 5.844 & Accepted \\
\hline H7 & Perceived Quality $\rightarrow$ Loyalty & 0.578 & 7.111 & Accepted \\
\hline
\end{tabular}




\section{CONCLUSIONS}

There are quality indicators, identified by researchers into the Cybermedia, which are commonplace in certain domains (banking, tourism, e-commerce, libraries, etc.), and may be used in the dimensions of analysis of perceived quality via the E-S-QUAL method. Similarly, there are also quality indicators used for Cybermedia, which may be used in the measurement scale of perceived quality and grouped into characteristic dimensions of E-S-QUAL models.

Reliability and privacy can be treated as a single dimension; this confirms Sánchez Franco (2008), who supported the fact that in the perceived quality of a website, the ability to perform the service reliably and securely, as a whole, was valued by the user. There is also relationship between efficiency and reliability and privacy; a Website that works well, is well linked, updated and easily accessible builds trust in the user. Likewise, multimediality is found to be a variable belonging to the interaction dimension (Vázquez et al., 2009).

There is a relationship between reliability and privacy, and interaction with the user. As mentioned previously, it can be stated that a user whose trust derives from a positive experience with regard to the provision of information and personal data will generate a better predisposition when it comes to interacting with the same Website. However, it is the relationship between perceived quality and efficiency that is most valued by users.

Moreover, the fact that there is a direct and positive relationship between perceived quality and reliability and privacy, as well as between perceived quality and interaction is highlighted. Users look for convenience, speed and connection between the different media, applications and platforms they frequent, while they wish to relate with the communications medium they visit and, in turn, do so with ease and without effort.

In addition, a positive experience with the Cybermedium leads to greater satisfaction and loyalty of the Internet user. On this point, and based on the data obtained, the users surveyed would lead the conclusion that their satisfaction and loyalty towards a medium will be higher the better their overall assessment of it.

In short, the e-SQ-MEDIA is a valid and reliable measurement scale of perceived quality in Cybermedia. The model considers and highlights not only the relationship between the dimensions and perceived quality but also that between the perception of quality and user satisfaction and loyalty. In this way, it has been possible to establish the most important elements when designing an information portal, and obtain a set of variables that combine the two areas of study, to enable the adoption of the necessary measures with a view to increased user uptake and hence improved competitiveness in the market of online newspapers.

Finally, regardless of whether subsequent studies are based on, develop or expand the eSQ-MEDIA scale, on the basis of the present research work, they will have a set of valid and reliable tools, and a theoretical base which, as a starting point, demonstrates that not only can the two areas of knowledge, Cybermedia and perceived quality, be studied as a whole but, in addition, they complement each other at theoretical and practical levels. 


\section{Limitations and future lines of research}

First and foremost, and from the outset, this research avoids all purely journalistic style or literary content, or the hedonistic nature that determines users' decisions. Journalistic content is not analyzed, because in this first approach the authors resort to the E-SQUAL model, which is used to analyse the quality of service and particularly the structure in which it operates, not the product. As an example, the same applies to the models of Yang and Tsai (2007) and Marimon et al. (2010). In the near future the authors intent to start work on a model that also takes journalistic content into account. Segre.com will be used because although it is a local online medium, its structure and tools are the same as those used by other national or international newspapers available in Web 2.0.

Thus, it was initially found that there was virtually no literature that deals with the subject of perceived quality and Cybermedia together, with the works of Codina (2000) and Rodríguez-Martínez et al., (2012) best approaching the studies of the present research. In addition, despite not being a hindrance for obtaining valid data, a higher sample level would have been desirable, although it was already taken into account that a local medium was targeted as a starting point. This was a restriction when studying the implementation of payment models, since very few data were available on the subject to be able to carry out as reliable and valid an analysis as possible.

The future lines of research proposed are based on the very limitations of the present study. One cannot, for example, turn a blind eye on the emotional implications that a customer has when taking decisions or purely journalistic aspects that influence the readers when they opt for one digital medium or another. For example, system availability in this first model cannot be ignored, because the goal was to use the basic dimensions of the original E-S-QUAL and investigate if these dimensions can be applied in a Cybermedium.

Despite the fact that for this type of research some authors such as Fabrigar et al., (1999) recommend a sample size greater than 200, and although the present research uses 211 valid surveys, this sample can be increased in future studies.

The measurement scale has to be applied to more complex media, of a domestic and an international scope, as well as to other formats such as radio and television. The research should also be extended to study the effects of including payment models in information portals or their evolution on those Websites where they are already set up, and examine the extent to which they are a determining factor. For example, the fact that there is no relationship between system availability and the other dimensions might be reason enough to replace the system availability dimension with another one, such as content or Web 3.0 (related with semantic web, geolocation, expanded web or data mining optimization), as a way to analyse how to connect the needs of the audience with the information offered by a Cybermedium. 


\section{REFERENCES}

Alén, M.E., Fraiz, J.A. (2006). Relación entre la calidad de servicio y la satisfacción del consumidor. Su evaluación en el ámbito del turismo termal. Investigaciones Europeas de Dirección y Economía de la Empresa, 12, (1), 251-272.

Ameer, I. (2014). Satisfaction. A behavioral perspective on consumer: Review, criticism and contribution. International Journal of Research Studies in Management, 3 (April), 1, 75-82. doi: 10.5861/ijrsm.2013.406

Auh, S., Johnson, M.D. (2005). Compatibility Effects in Evaluations of Satisfaction and Loyalty. Journal of Economic Psychology, 256, 35-57. doi: 10.1016/j.joep.2003.10.002

Bagozzi, R., YI, J. (1988). On the Evaluation of Structural Equation Models. Journal of the Academy of Marketing Science, 16, (1), 74-94. doi: 10.1007/BF02723327

Barnes, S.J., Vidgen, R.T. (2002): An integrative approach to the assessment of ecommerce quality. Journal of Electronic Commerce Research, 3, (3), 114-227. doi: 10.1016/j.im.2006.06.001.

Broekhuizen, T., Hoffman, A. (2012). Interactivity perceptions and on-line newspapers preference. Journal of Interactive Advertising, 12, (2), 29-43.

Carpentier, N. (2011). Contextualising autor-audience convergences: New technologies Claims to Increased Participation, Novelty and Uniqueness. Cultural Studies, 25, (4-5), pp. 517-533. doi: 10.1080/09502386.2011.600537

Casero-Ripollés, A. (2010). Prensa en Internet: nuevos modelos de negocio en el escenario de la convergencia. El profesional de la información, 19, 6, 595-601. doi: 10.3145/epi.2010.nov05.

Casero-Ripollés, A., Izquierdo-Castillo, J. (2013). Between Decline and New Online Business Model: The Case of the Spanish Newspaper Industry. Journal of Media Business Studies, 10 (1), pp. 63-78. doi: 10.1080/16522354.2013.11073560.

Castillo, V.R., Sánchez Romero, M.C. (2010). Identificación y análisis estadístico de variables que afectan el comportamiento de adquisición de servicios a través de Internet en la región de Orizaba, México. Premium, Revista de Economía, Finanzas y Negocios, $11,1-17$.

Cebrián, M. (2009). Comunicación interactiva en los Cibermedios Revista Comunicar, 17, 15-24. doi: 10.3916/c33-2009-02-001.

Cely, A. (2004). Cibergrafía: propuesta teórico metodológica para el estudio de los medios de comunicación social cibernéticos. Opción, 43, 101-118.

Codina, Ll. (2000). Evaluación de recursos digitales en línea: conceptos, indicadores y métodos. Revista española de Documentación Científica, 23, (1), 9-44. doi: 10.3989/redc.2000.v23.i1.315 
Cristóbal, E., Flavián C., Guinalíu M. (2007). Perceived e-service quality (PESQ): measurement validation and effects on consumer satisfaction and website royalty. Managing Service Quality. 17, (3), 317-340. doi: 10.1108/09604520710744326

Cristóbal, E., Gómez-Adillón, M. J. (2004). La situación de la venta de contenidos on line en España. Un estudio del lector de prensa digital. Boletín Económico de ICE, 2793, 17-23.

Cronin J., Taylor, S. (1992). Measuring Service Quality: A Reexamination and Extension. Journal of Marketing, 56, 55-68.

De La Fuente, H., Díaz I. (2013). Análisis de los factores determinantes de la calidad percibida del servicio prestado por una cooperativa de ahorro y crédito: una aplicación basada en modelos de ecuaciones estructurales. Ingeniare. Revista chilena de ingeniería, 2, (21), 232-247. doi: 10.4067/S0718-33052013000200007

Díaz-Noci, J. (2005). Historia de los cibermedios en España. En: Cibermedios. El impacto de Internet en los medios de comunicación en España. Sevilla: Comunicación Social, Ediciones y Publicaciones. 21-38.

Díaz-Noci, J., Palacios, M. (2008). Ciberperiodismo: métodos de investigación. Bilbao: Servicio Editorial de la Universidad del País Vasco.

Díaz-Noci, J., Salaverría, R. (2003). Manual de Redacción Ciberperiodística. Barcelona: Ariel.

Espejel, J. E., Fandos, C., Flavián, C. (2007). Modelo de ecuaciones estructurales aplicado al aceite de oliva virgen extra del bajo Aragón con Denominación de origen protegida. Revista Mexicana de Agronegocios, 11, (20), 222-237.

Fabrigar, L.R., Wegener, D.T., Maccallum, R.C., Strahan, E.J. (1990). Evaluating the use of exploratory factor analysis in psychological research. Psychological Methods, 4 (3), 272-299. doi: $10.1037 / 1082-989 X .4 .3 .272$

Flavián, C., Guinaliu, M. (2006). La confianza y el compromiso en las relaciones a través de Internet. Dos pilares básicos del marketing estratégico en la Web. Cuadernos de Economía y Dirección de la Empresa, 29, 133-160.

Flavián, C., Gurrea, R. (2009). Factores determinantes de la actitud hacia los periódicos digitales. Revista Española de Investigación de Marketing ESIC, 13, (2), 53-71.

Fornell, C., Larcker, D.F. (1981). Evaluating Structural Equation Models with Unobservable Variables and Measurement Error. Journal of Marketing Research, 18, (1), 39-50.

Franklin, B. (2011). The Future of Journalism. London: Routledge.

Gallardo, F. (2011). Nuevos modelos de negocio para la prensa. Telos: Revista de Pensamiento sobre Comunicación, Tecnología y Sociedad, 86. 
Garín, T., Pérez Amaral, T. (2011). Factores Determinantes del Comercio Electrónico en España. Boletín Económico de ICE, 3015, 51-65.

Garrido, L.E., Shih, P.C., Martínez-Molina, A. (2012). EBA-Q: Evaluación de la Calidad Percibida de los servicios de biblioteca y Archivo de la Universidad Autónoma de Madrid. Universidad autónoma de Madrid.

Herbert, J., Thurman, N. (2007). Paid content strategies for news websites. Journalism Practice, 1, (2), 208-226. doi: 10.1080/17512780701275523

Hernández Soriano, F., Cristóbal, E. (2013): Estado de la cuestión y nuevas perspectivas en la evaluación de la calidad percibida en cibermedios. Historia y Comunicación Social, 18, 15-27. doi. 10.5209/rev_HICS.2013.v18.44222

Hernández-Soriano F., Cristóbal E. (2014). Evaluación de las herramientas Web 2.0 en el periodismo digital: el caso de VilaWeb. Revista Historia y Comunicación Social. 19. 79-91. doi: 10.5209/rev_HICS.2014.v19.44942

Jacoby, J., Chestnut, R.W. (1978). Brand Loyalty Measurement and Management. New York: Wiley \& Sons.

Janita, M.S., Miranda, F.J. (2008). Las dimensiones de la e-calidad como fuente de ventaja competitiva. Boletín económico de ICE, 2944, 47-61.

Kaye, B., Johnson T. (2004). A web for all reasons: uses and gratifications of Internet components for political information. Telematics and Informatics. 21. 197-223. doi: $10.1016 / \mathrm{S} 0736-5853(03) 00037-6$

Kawamoto, K. (2003). Digital Journalism. Emerging Media and the Changing Horizons of Journalism. Maryland: Rowman\&Littlefield Publishers.

Khan, I. (2012). Impact of Customers Satisfaction and Customers Retention on Customer Loyalty. International Journal of Scientific \& Technology Research, 1, (2), 106-110.

Kim, K.J., Yoon, C.H. (2004). Determinants of subscriber churn and customer loyalty in the Korean Mobile telephony market. Telecommunications policy, 28, 751-765. doi: 10.1016/j.telpol.2004.05.013

Lin, J.; Lu, H. (2000). Towards an Understanding of the Behavioural Intention to Use a Web Site. International Journal of Information Management, 20, (3), 197-208. doi: $10.1108 / 10662240810883326$

López, X., Limia, M., Isasi, A., Pereira, X., Gago, M., Calvo, R., Orihuela, J.L. (2005). Tipología de los Cibermedios. En: Cibermedios. El impacto de Internet en los medios de comunicación en España. Sevilla: Comunicación Social, Ediciones y Publicaciones, 46. 
Maier S. (2012). All the News Fit to Post? Comparing News Content on the Web to Newspapers, Television, and Radio. Journalism \& Mass Communication Quarterly September, 87, (3-4), 548-562. doi: 10.1177/107769901008700307

Manfreda, K.L., Bosnjak, M., Berzelak, J., Hass, I., Vehovar, V. (2008). Web Surveys versus Other Survey Modes - A Meta-Analysis Comparing Response Rates. International Journal of Market Research, 50, (1), pp. 79-104. doi: $10.1177 / 1525822 \mathrm{X} 08317085$.

Marimon, F., Cristóbal, E. (2012). La influencia de la calidad percibida en el sector de la distribución alimentaria por Internet: perspectiva multidimensional aplicada a un supermercado on-line. Revista de Estudios Empresariales. 1, 131-148.

Marimon, F., Vidgen R., Barnes, S., Cristóbal, E. (2010). Purchasing behaviour in an on-line supermarket. The applicability of E-S-QUAL. International Journal of Market Research, 52, (1), 111-130. doi: 10.2501/S1470785310201089

Meso, K. (2007). El impacto de Internet en los medios de comunicación vascos. $1^{\mathrm{a}}$ ed. Bilbao: Servicio Editorial de la Universidad del País Vasco.

Mcdonald, R.P.; Ho, M. R. (2002). Principles and Practice in Reporting Structural Equation Analyses. Psychological Methods, 7, (1), 64-82. doi: 10.1037/1082989X.7.1.64

Mcllroy, A., Barnett, S. (2000). Building customer relationships: do discount cards work?. Managing service Quality, 6, 347-355. doi:

http://dx.doi.org/10.1108/09604520010351491

Nah, S., Yamamoto M., Chung D. S., Zuercher R. (2015). Modeling the Adoption and Use of Citizen Journalism by Online Newspapers. Journalism \& Mass Communication Quarterly. 92, (2), 399-420. doi: 10.1177/1077699015574483

Nunnally, J., Bernstein, J. (1994). Psychometric Theory New York: McGraw Hill, 3rd ed.

O'Reilly, T. (2005). What is Web 2.0. Design Patterns and Business Models for the Next Generation of Software. http://www.oreilly.com/pub/a/web2/archive/what-isweb-20.html. Accessed 20 june 2015.

Oliver, R.L. (1997). Satisfaction. A Behavioural Perspective on the Consumer. New York: McGraw-Hill.

Palacios, M., Díaz-Noci, J. (2009). Online journalism: research methods. A multidisciplinary approach in comparative perspective. Bilbao: Servicio Editorial de la Universidad del País Vasco.

Parasuraman A., Zeithaml, V., Berry, L. (1985), A conceptual model of service quality and its implications for future research. Journal of Marketing, 49, (4), 41-50. doi: $10.2307 / 1251430$. 
Parasuraman, A., Zeithaml, V., Berry, L. (1988). SERVQUAL: A Multiple-Item Scale for Measuring Costumer Perceptions of Service Quality. Journal of Retailing, 64, (1), 12-40. doi: 10.1016/S0148-2693(99)00084-3.

Parasuraman. A., Berry. L. L., Zeithaml. V. A. (1991). Refinement and reassessment of the SERVQUAL scale. Journal of Retailing, 67, (4), 420-450. doi: 10.1111/j.14388677.2010.00335.x

Parasuraman, A., Zeithaml, V., Malhotra, A. (2005): E-S-QUAL: A Multiple-Item Scale for Assessing eElectronic sService Quality, Journal of Retailing, 1, (64), 12-40. doi: $10.1177 / 1094670504271156$

Parra, D. (2008). El diseño ciberperiodístico español: análisis de los casos de VilaWeb y ADN.Enl@ce; Revista Venezolana de Información, Tecnología y Conocimiento. 5 (3) 91-107.

Parra, D., Edo, C., Flores, J., García-Alonso, P., Marcos, J. (2008). Proceso de transformación de los cibermedios: los retos de las empresas periodísticas. Revista Latina de Comunicación Social, 63, 63-70. doi: 10.4185/RLCS-63-2008-749-063-070

Pérez Luque, M.J., Perea, M. (1998). El reto de crear noticias on-line. Análisis de la comunicación on-line actual y perspectivas de futuro, Cuadernos de Documentación Multimedia, 6-7.

Petnji, L., Marimon, F., Casadesús, M. (2012). Assessing e-service quality: the current state of E-S-QUAL, Total Quality Management Business Excellence, 23, 1363-1378. doi: $10.1080 / 14783363.2012 .728850$

Picard, R. (2011). The economics and financing of media companies. New York: Fordham University Press.

Prado, A., Blanco, A., Mercado, C. (2013). Satisfacción, lealtad y compromiso en entornos on-line. Esic Market Economics and Business Journal, 44, (2), 167-189. doi: 10.7200/esicm.145.0442.4e.

Rebolloso, E., Salvador, C., Fernández, B., Cantón, P. (2004). Análisis y ampliación del SERVQUAL en los servicios universitarios. Revista de Psicología del Trabajo y de las Organizaciones. 20, (3), 355-373.

Rodríguez-Gairín, J.M. (2001). Parámetros e indicadores de calidad en la evaluación de una revista electrónica. El caso de $\mathrm{BiD}$. BiD, Textos universitaris de biblioteconomía $\mathrm{i}$ documentació. 6. June. 1-20.

Rodríguez-Martínez, R., Codina, Ll., Pedraza, R. (2010). Cibermedios y Web 2.0: Modelo de Análisis, resultados de la aplicación. El profesional de la información. 19, (1), 35-44. doi: 10.3145/epi.2010.ene.05

Rodríguez-Martínez, R., Codina, Ll., Pedraza, R. (2012). Indicadores para la evaluación de la calidad en Cibermedios: análisis de la interacción y de la adopción de la Web 2.0. 
Revista Española de Documentación Científica, 35, (1), 61-93. doi: $10.3989 /$ redc. 2012.1 .858

Said, E., Arcila C. (2011). Los cibermedios en América Latina y la Web 2.0. Revista Comunicar, 19, (37), 125-131. doi: 10.3916/C37-2011-03-04

Salaverria, R. (2003) An inmature medium. Strenghts and Weaknesses of On-line Newspapers on September 11. The International Journal for Communication Studies, 67, (1), 68-86. doi: 10.1177/0016549205049179

Salaverría, R. (2005). Cibermedios. El impacto de Internet en los medios de comunicación en España. Sevilla: Comunicación Social Ediciones y Publicaciones.

Sánchez Franco, M. (2008). La calidad percibida del website: un factor de influencia sobre el valor de la marca. Investigación y Marketing, 76, 55-62.

Semeijn, J., Van Riel, A., Van Birgelen, M., Streukens, S. (2005). E-services and offline fulfilment: how e-loyalty is created. Managing Service Quality: An International Journal, 15, (2), 182-194. doi: 10.1108/09604520510585361

Streiner, D.L. (2003). Starting at the beginning: an introduction to coefficient alpha and internal consistency. Journal of Personality Assessment, 80, (1), 99-103. doi: 10.1207/S15327752JPA8001_18

Thorson E., Wicks R., Leshner G. (2012). Experimental Methodology in Journalism and Mass Communication Research. Journalism \& Mass Communication Quarterly March, 89, (1), 112-124. doi: 10.1080/10410236.2014.974123

Vandenbosch, M. (1996). Confirmatory Compositional approaches to the development of product spaces. European Journal of Marketing, 30, (3), 23-46. doi: 10.1108/03090569610107418.

Vázquez Casielles, R., Río Lanza, A.B., Suárez Álvarez, L. (2009). Las agencias de viaje virtuales: ¿Cómo analizar la calidad de e-servicio y sus efectos sobre la satisfacción del cliente?. Universia Business Review, 24, 122-143. doi: $10.1080 / 14783363.2014 .895523 \cdot 0.59$

Wurff, R., Lauf, E., O’Sullivan, J. (2005). Print and online newspapers in Europe: a comparative content analysis in 16 countries in Western and Eastern Europe. Amsterdam: Het Spinhuis, 326.

Yaghi, D. (2010). A customised scale for measuring retail service quality in a college shop: a context specific approach. Doctoral thesis. Northumbria University. http://nrl.northumbria.ac.uk/2406/. Accessed 20 June 2015.

Yang, H, Tsai, F. (2007). General E-S-QUAL Scales Applied To Websites Satisfaction and Loyalty Model. Communications of the IIMA 117, 7, (2), 115-126.

Zeithaml, V., Parasuraman, A., Malhotra, A. (2000). A conceptual framework for understanding e-service quality: Implications for future research and managerial practice. MSI Working Paper Series, 115, 1-49. 